\title{
THE EXTENT TO WHICH ARABIC TEACHERS PRACTICE DIFFERENTIATED INSTRUCTION SKILLS IN THE SECOND CYCLE OF BASIC EDUCATION IN THE SULTANATE OF OMAN
}

http://dx.doi.org/10.47832/2757-5403.3-3.1

Mohammed Saleh ALAJMI 1

\begin{abstract}
:
This study aimed to know the extent to which Arabic language teachers practice differentiated teaching skills in the second cycle of basic education in the Sultanate of Oman, and to reveal whether there are statistically significant differences at the significance level $(a \leq 0.05)$ due to the variables of the human gender and the educational governorates in the extent of practicing Differentiated teaching skills. The study adopted the descriptive approach, and its community consisted of all the first teachers and the first teachers of the Arabic language in the General Directorates of Education in the governorates: North and South Al-Batinah, Muscat, Al-Dakhiliyah and Dhofar, which numbered 175 teachers first and a first teacher, while the study sample was chosen by a simple random method at a rate of $75 \%$ It has reached 132 first and first female teachers, and to achieve the aims of the study, a differentiated education skills questionnaire was designed and applied, consisting of three axes: the planning axis for differentiated education, the implementation axis for differentiated education, and the evaluation axis for differentiated education. Among the findings of the study: The extent to which Arabic language teachers practiced differentiated teaching skills in the second cycle of basic education in the Sultanate of Oman was of a medium degree, with an arithmetic mean of 3.16 , while the study revealed statistically significant differences attributed to the gender variable in favor of the female teachers. The extent of application of differentiated education skills in the second cycle of basic education in the Sultanate of Oman in the axis of implementation of differentiated education, and in contrast there were no statistically significant differences attributed to the educational governorate variable in the extent of application of differentiated education skills in the second cycle of basic education in the Sultanate of Oman. Among the most prominent recommendations that came out of the study: Promoting Arabic language teachers in the second cycle of basic education who practice differentiated education. To increase the demand for it in teaching practices to high levels. And increasing interest in training

\footnotetext{
${ }^{1}$ Dr. , Suhar University, Sultanate of Oman, Majmi3@su.edu.om, https://orcid.org/0000-0002-6882-7608
}

Copyright $(\mathcal{C}$ Published by IJHER Journal, www.ijherjournal.com Rimar Academy, Fatih, Istanbul, 34093 Turkey

All rights reserved 
programs for Arabic language teachers in the second cycle of basic education to raise the scope of differentiated education practice to high levels.

Key words: Differentiated Education, Cycle Two, Sultanate of Oman.

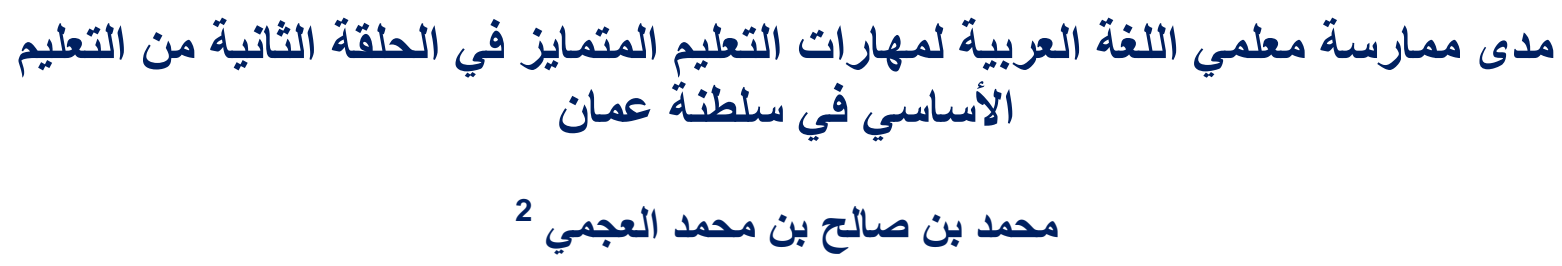

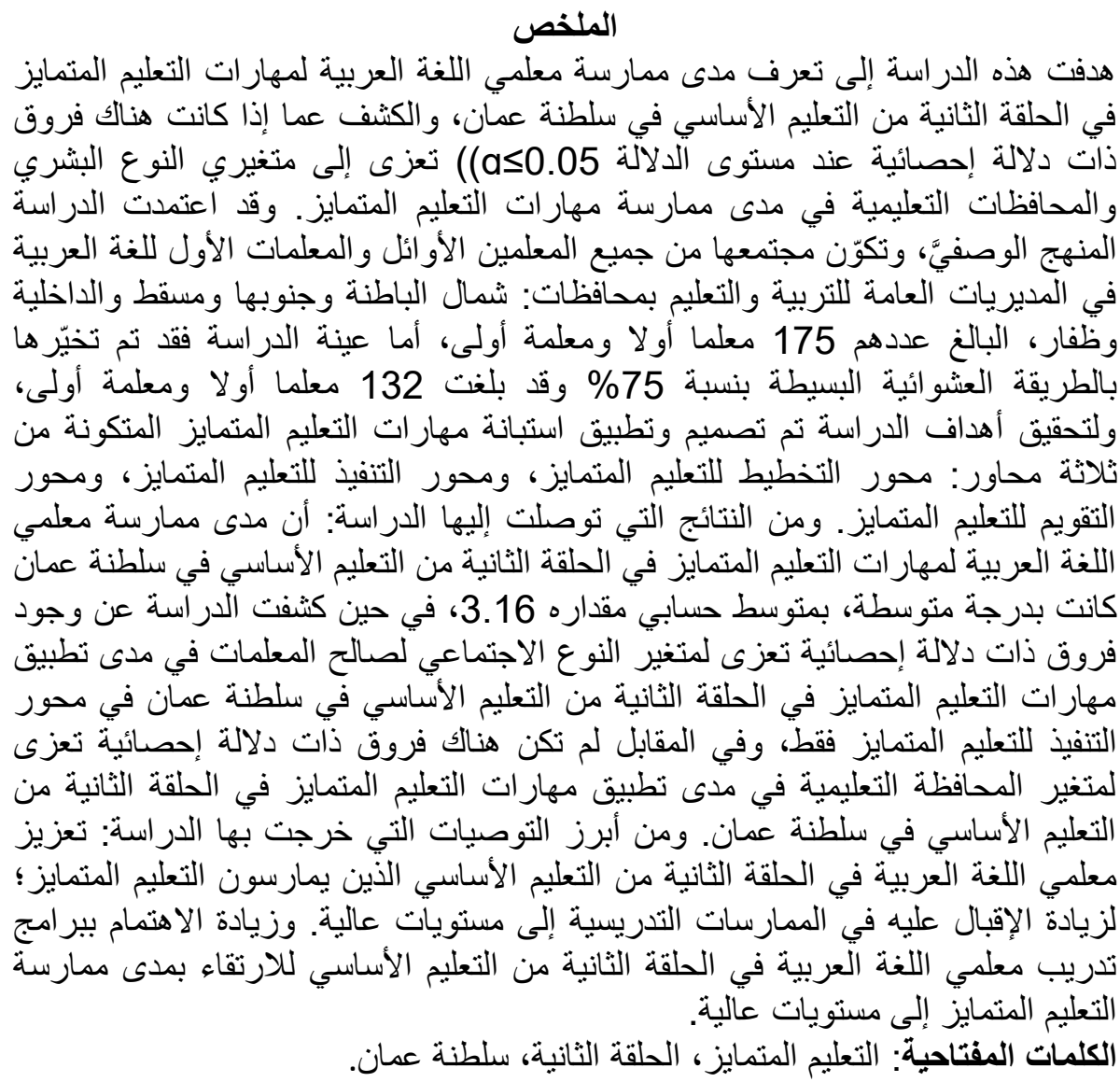

المقدَّمة:

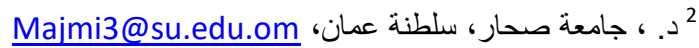




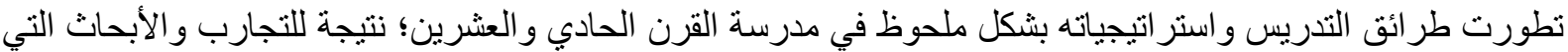

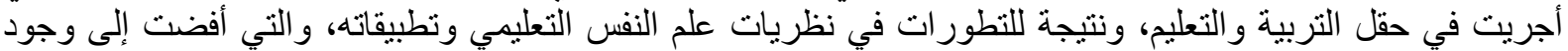

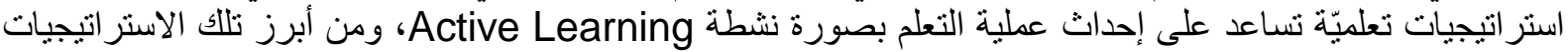

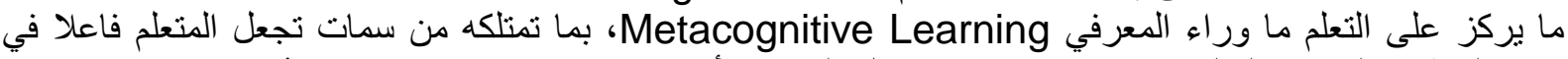

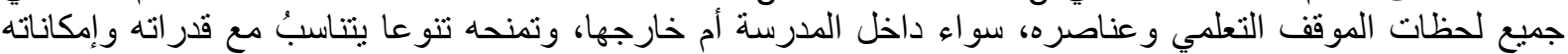
وكفاياته وميوله التعلمية.

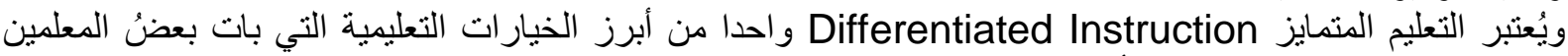

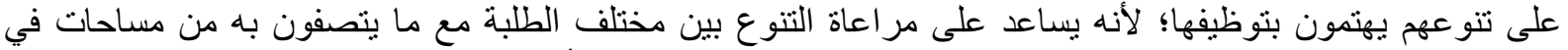

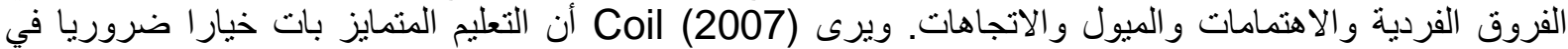

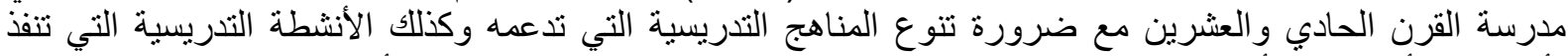

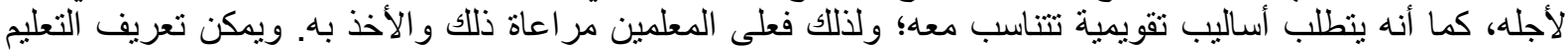

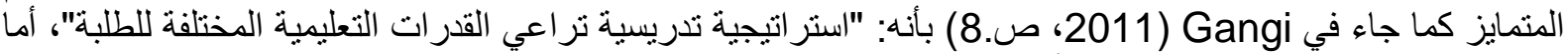

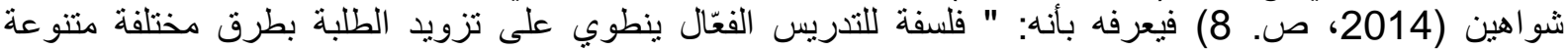

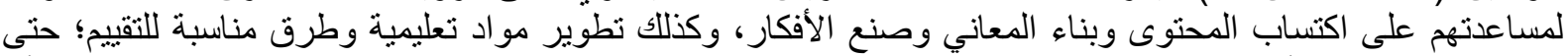

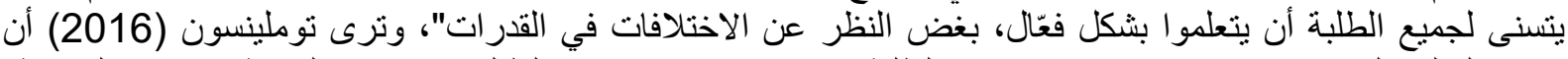

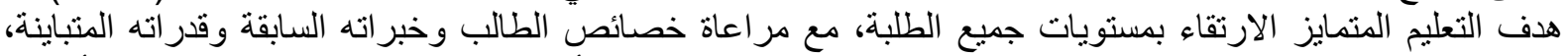

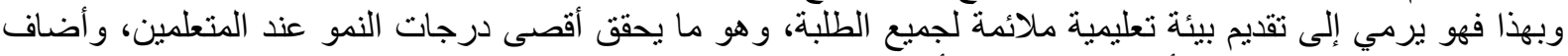

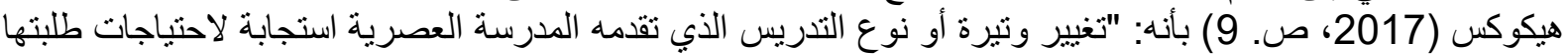

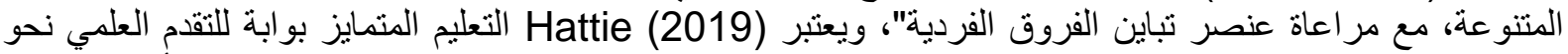

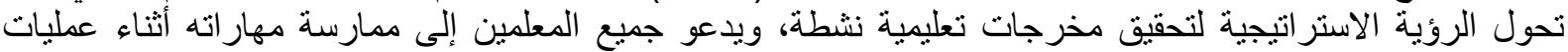

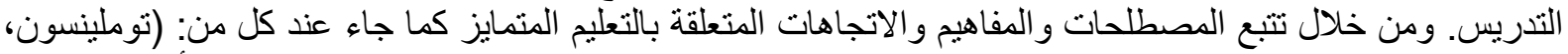

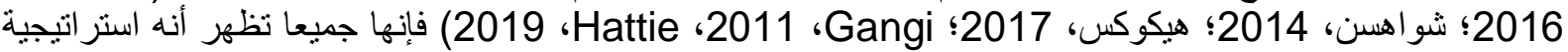

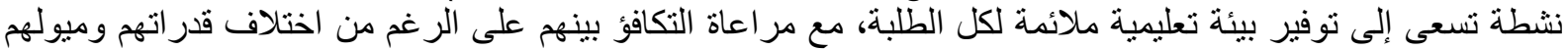

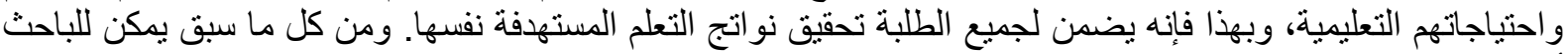

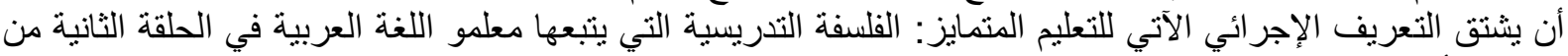

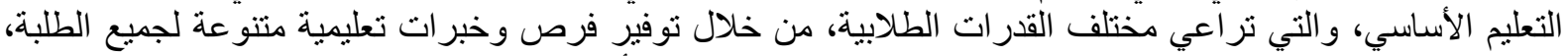

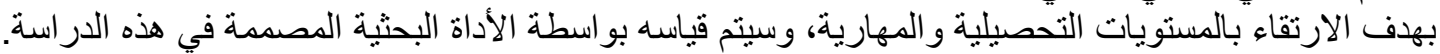

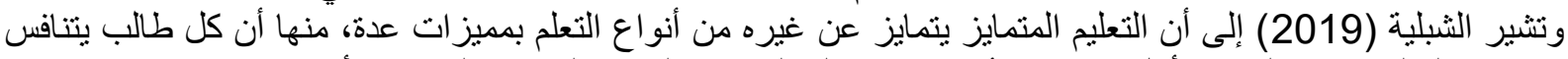

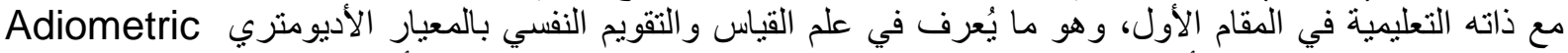

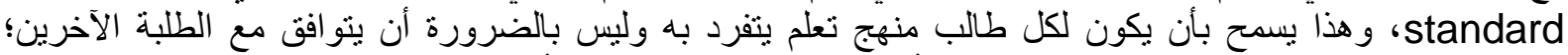

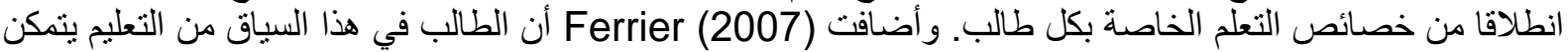

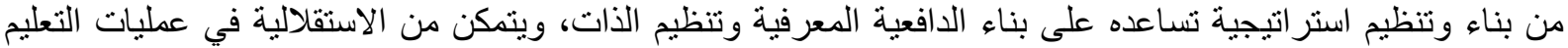

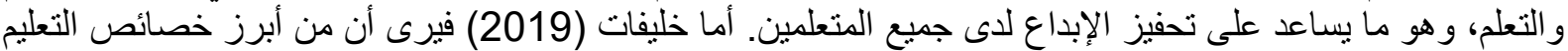

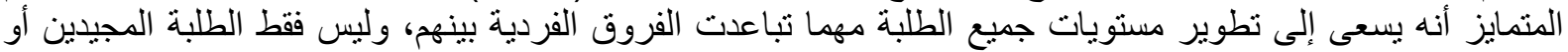

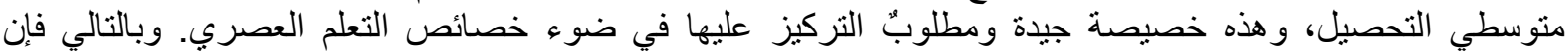

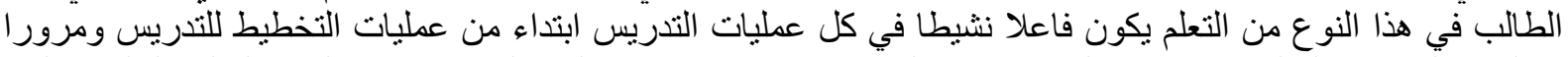

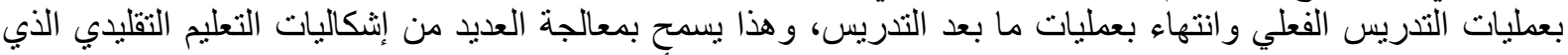

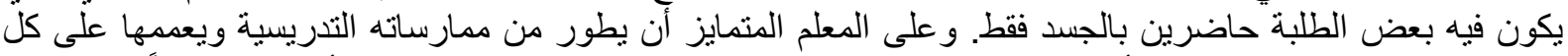

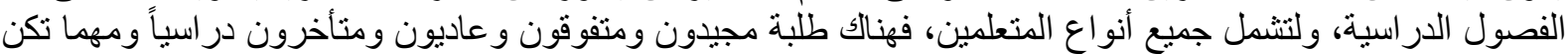

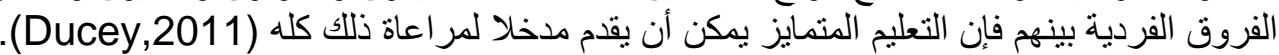

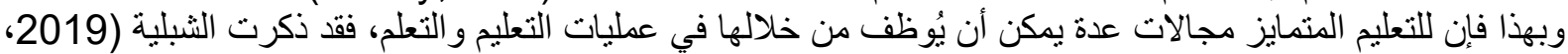

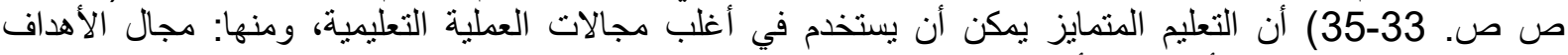

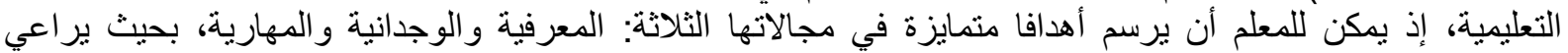

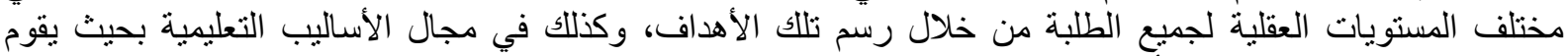

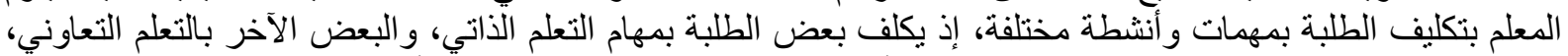

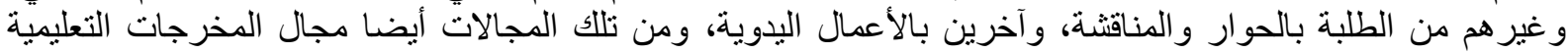

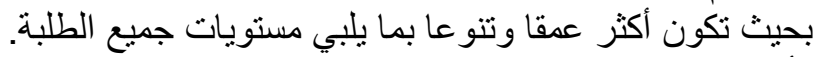

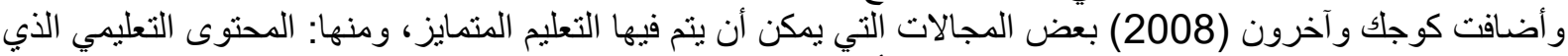

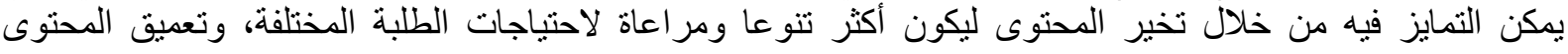




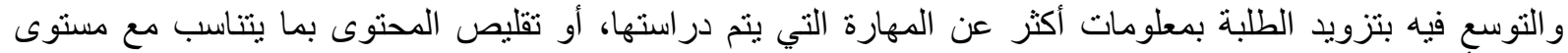

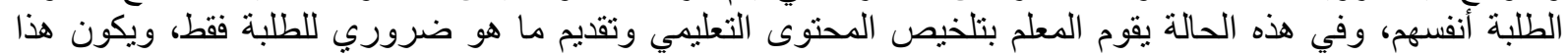

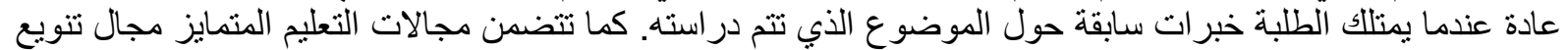

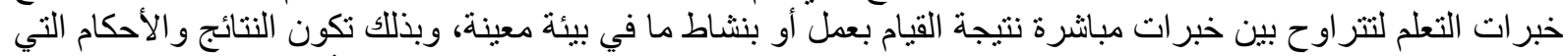

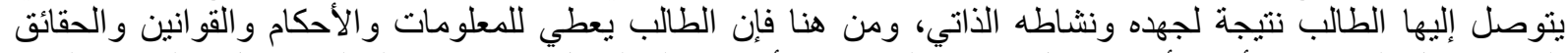

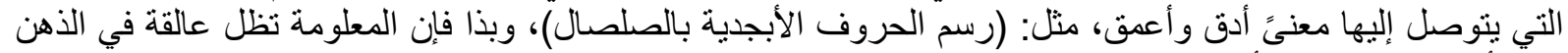

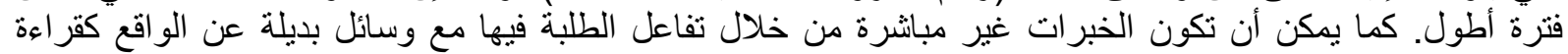

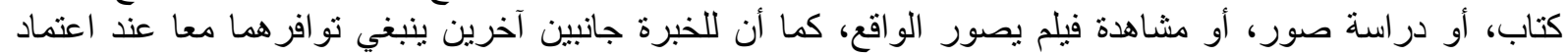

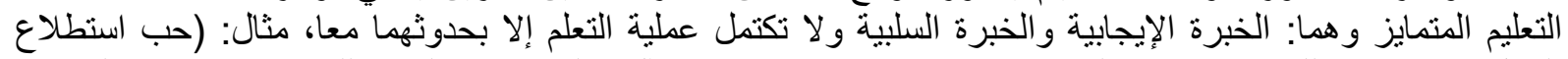

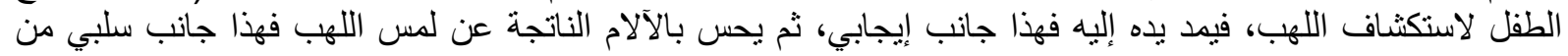

ومن المجالات التي يمكن أن يتم فيها التعليم المتمايز كما أكد عليها عطية (2013) مجال تنويع أدوات وأساليب التقويم

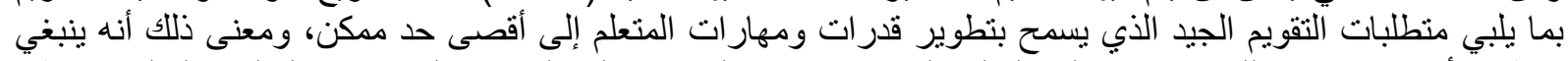

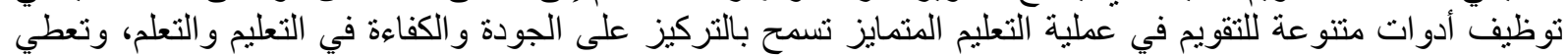

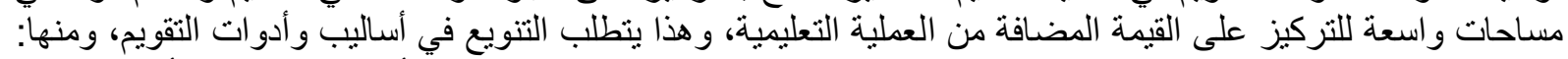

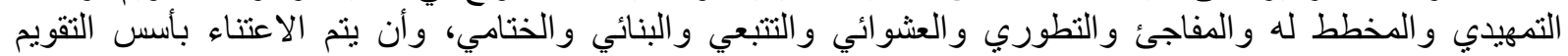

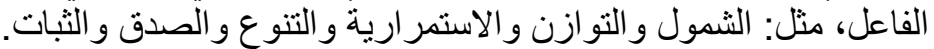

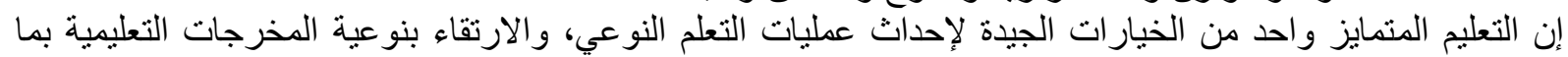

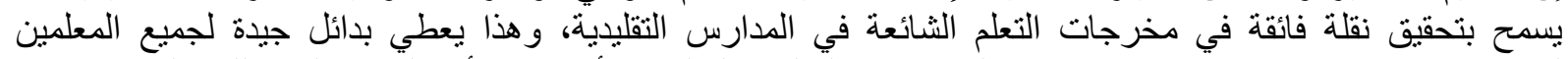

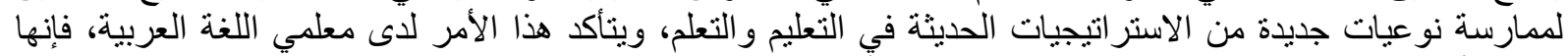

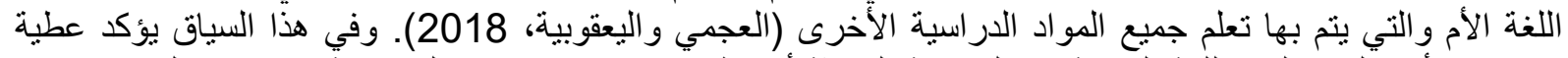

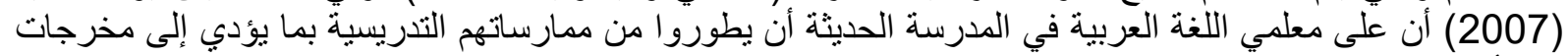

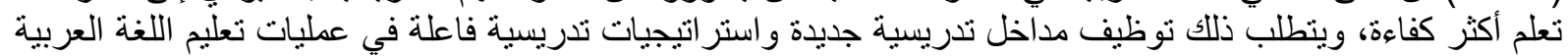

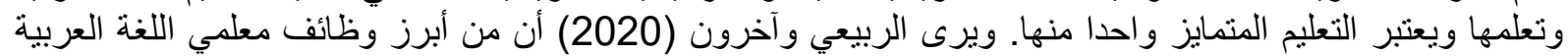

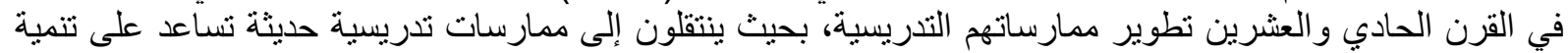

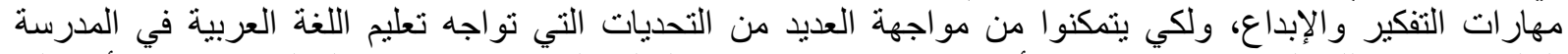

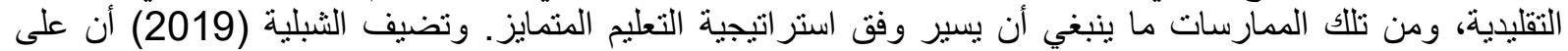

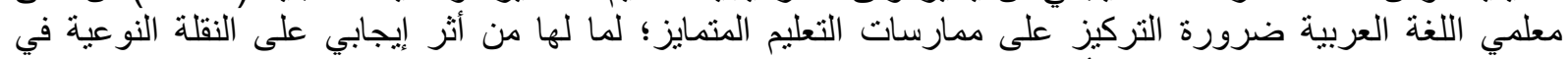

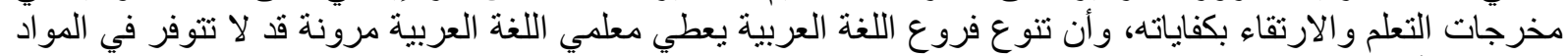

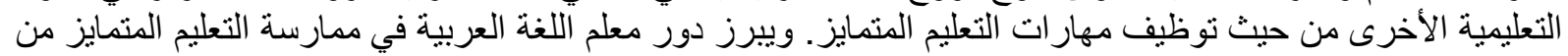

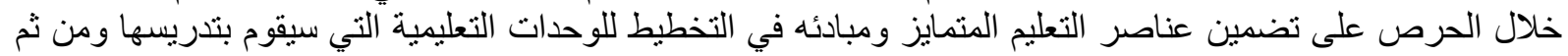

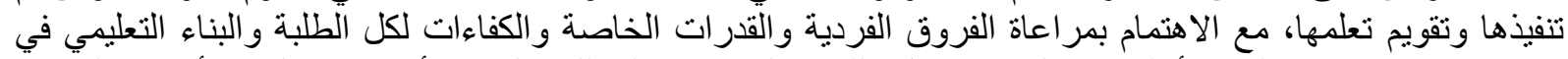

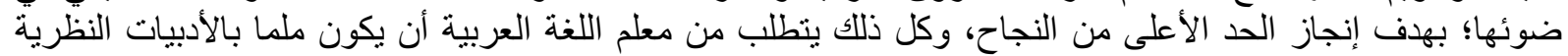

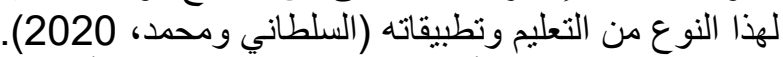

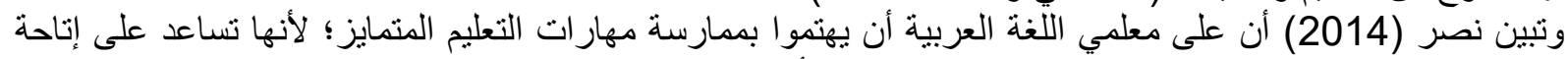

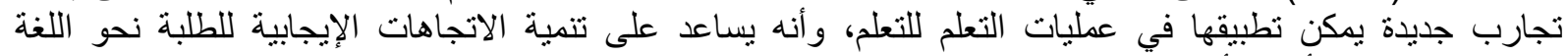

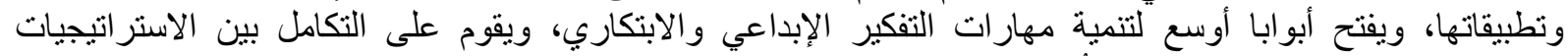

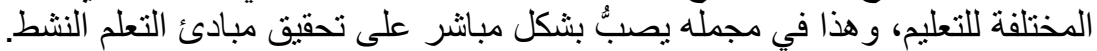

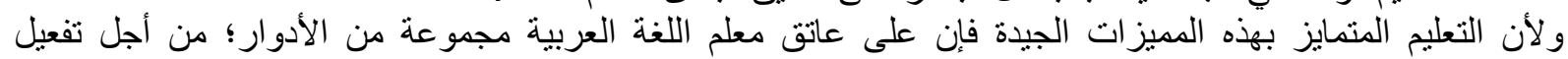

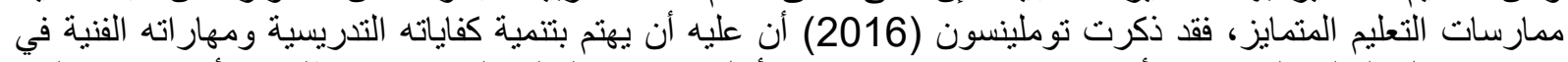

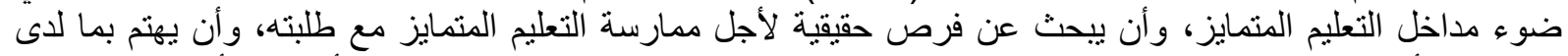

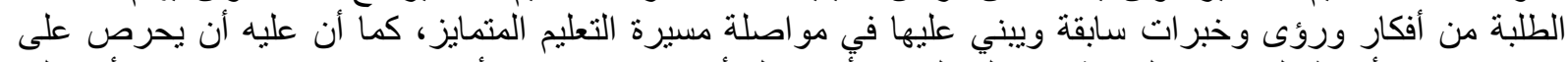

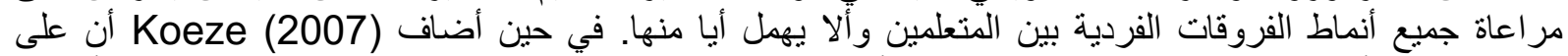

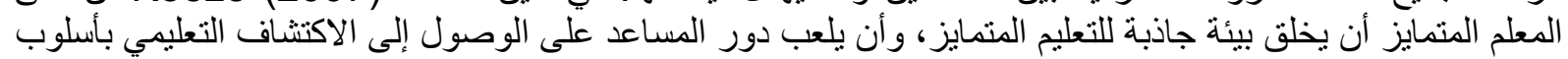

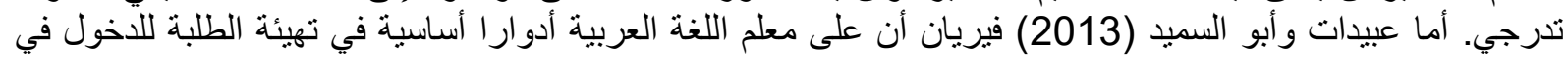


عالم التعليم المتمايز، وأن يحرص معلم اللغة العربية على ممارسة مهارات التعليم المتمايز في كل فرصة فئه ما أمكن ذلكه،

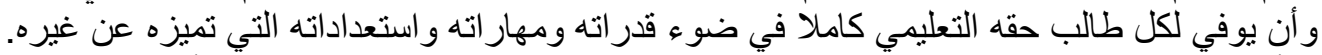

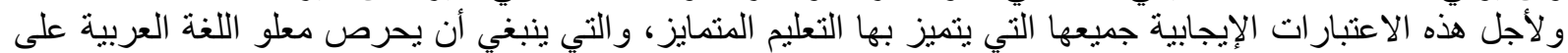

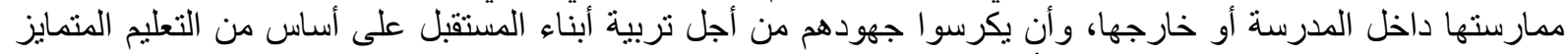

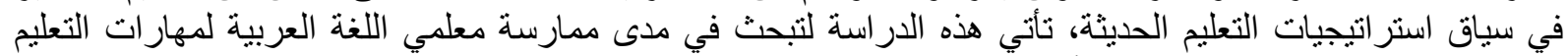
المنمايز في الحلقة الثانية من التعليم الأساسي في سلطنة التئي عمان.

مشكلة الاراسة

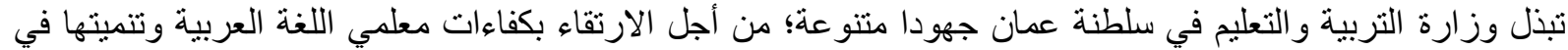

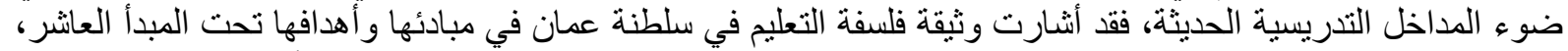

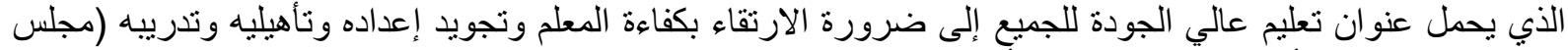

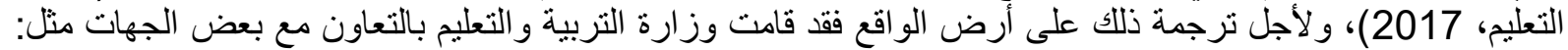

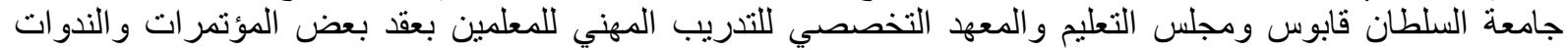

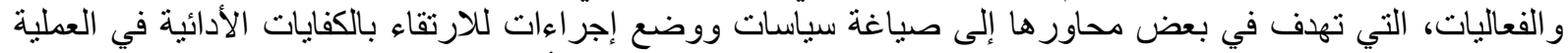

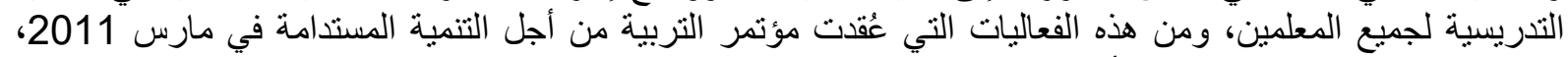

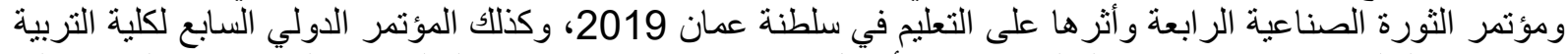

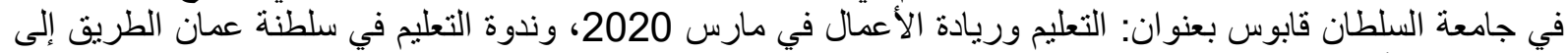

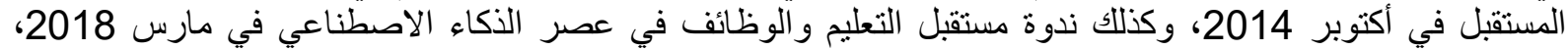
وتنقى كل هذه الجهود في سياق التخطبط الاستر اتيجي الذي ينطلب إجراء در استات لقياس مدى الالتز ام بالتنفيذ و التطبيق،

و انعكاساتها على ممارسات المعلمين في القاعة التحة التدريسية.

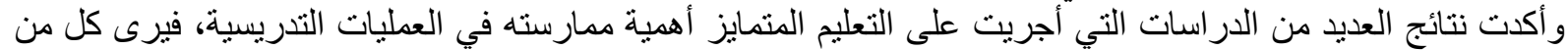
Stephen, Marlene, Gerard and Leela (2013)

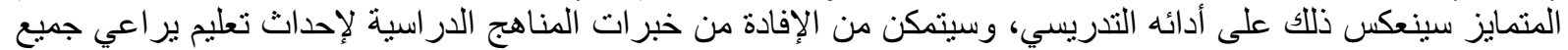

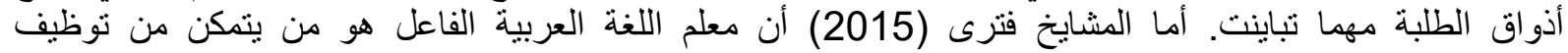

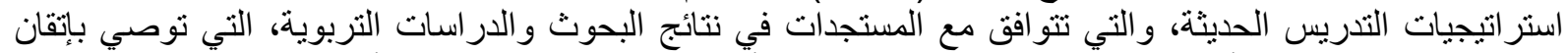

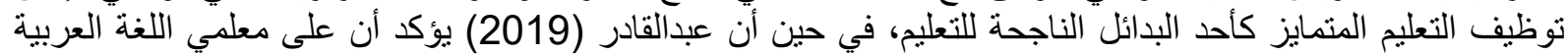

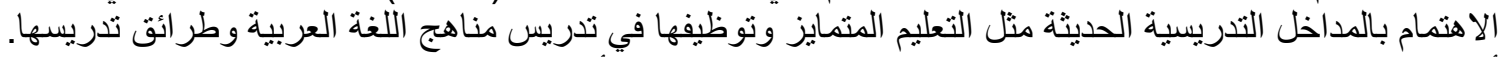

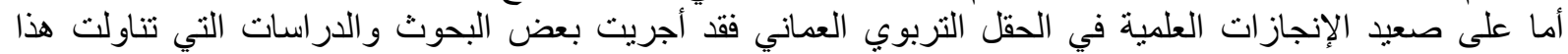

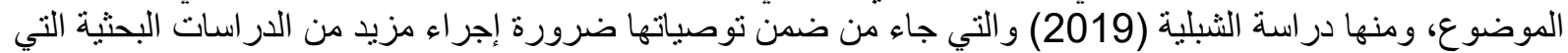

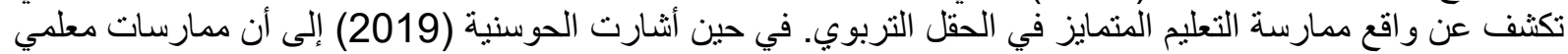

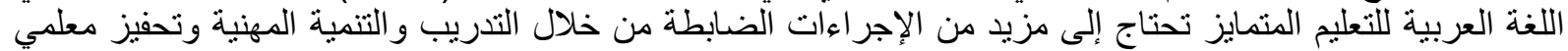

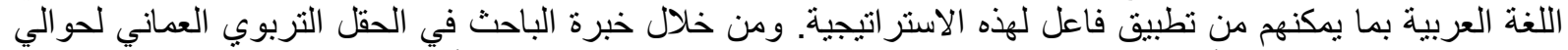

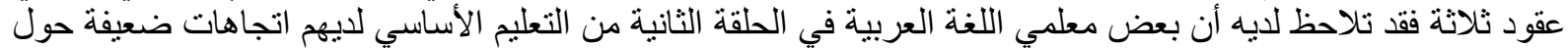

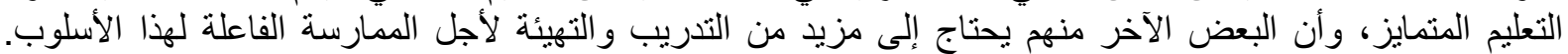

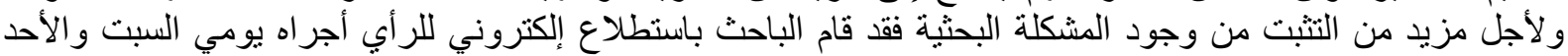

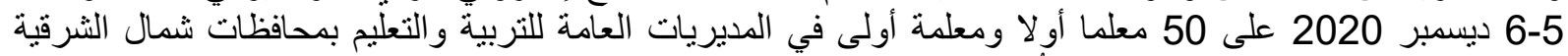

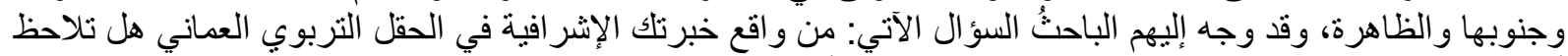

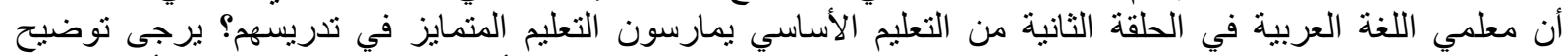

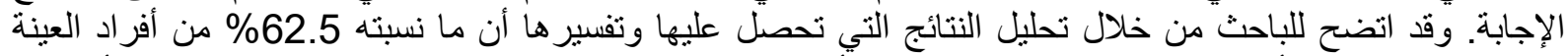

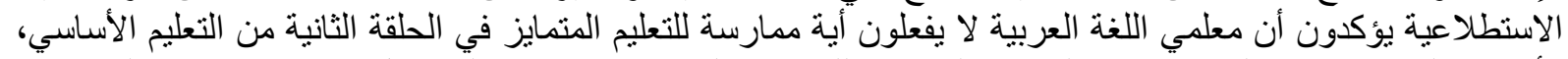

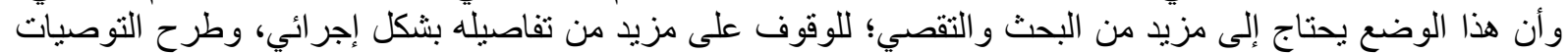

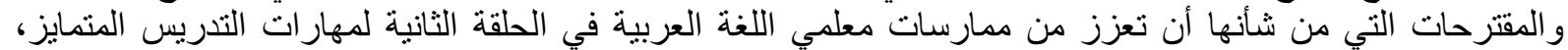
و انطلاقا من ذلك تأتي هذه الدراسة لتسد هذه الفجوة المعرفية في هذا الجانب. للفئ

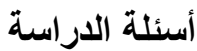

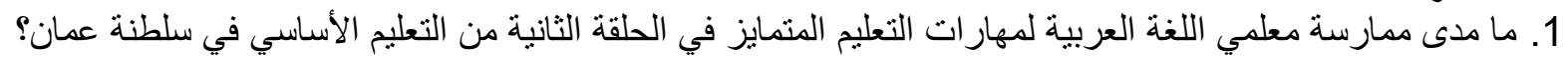

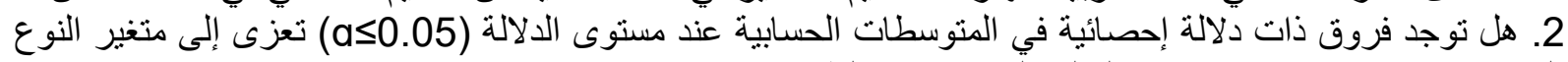

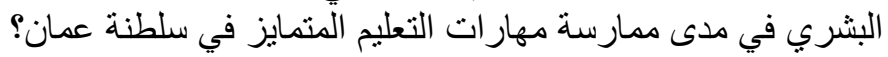


3. هل نوجد فروق ذات دلالة إحصائية في المتوسطات الحسابية عند مستوى الدلالة (as0.05) تعزى إلى متغير

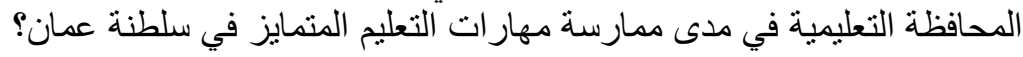

أهداف الاراسة 1. تعرف مدى ممارسة معلمي اللغة العربية لمهارات التعليم المنمايز في الحلقة الثانية من التعليم الأساسي في سلطنة عمان؟ نعرج

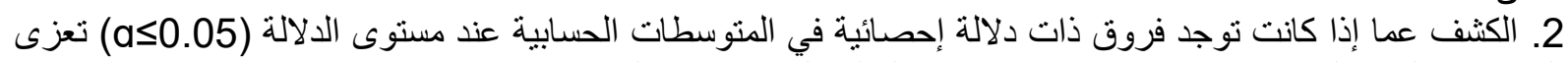

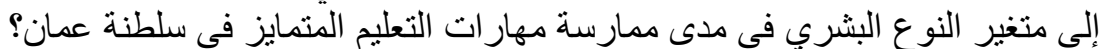

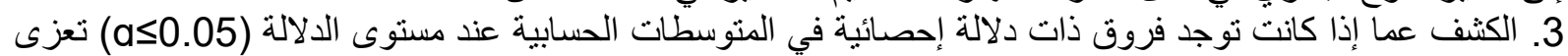

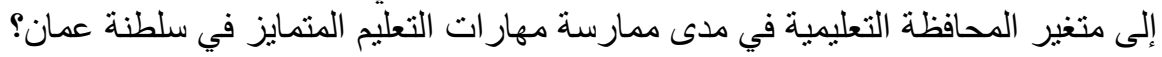

أهمية الاراسة

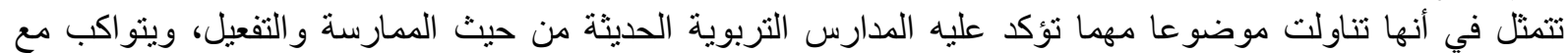

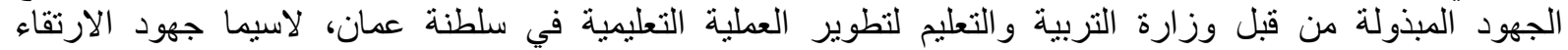

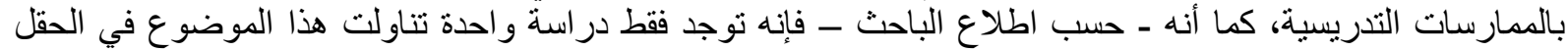

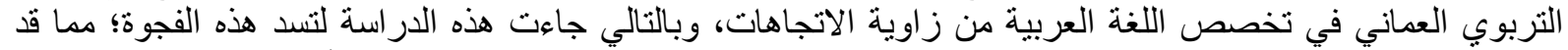

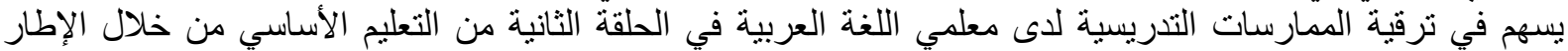

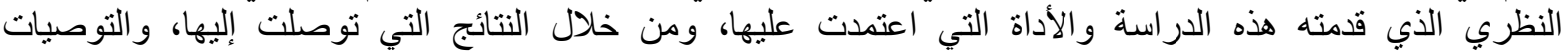

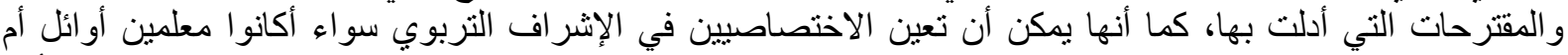

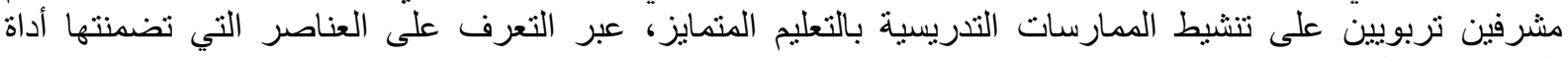
الدراسة وتفعيلها عمليا في الموقف التدريسي.

حدود الدراسة العوضة 1. الحدود الموضو عية: تتمثل في مدى ممارسة مهار الته التعليم المتمايز ، من حيث التخطبط و التنفيذ و التقويم. 2. الحدود البشرية: تتمثل في عينة من المعلمين الأوائل والمعلمات الأول للغة العينة العربية في الحلقة الثانية من التعليم الأساسي. 3. الحدود المكانية: تتمثل في كل من المحافظات التعليمية بشمال الباطنة وجنوب الباطنة ومسقط و الداخلية وظفار.

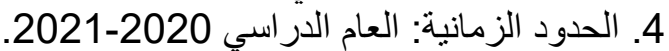

مصطحات الاراسة

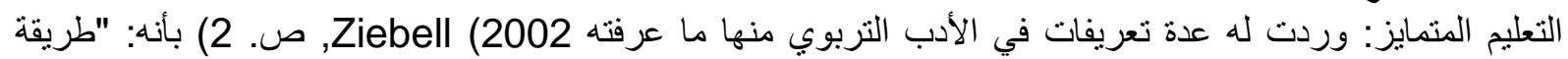

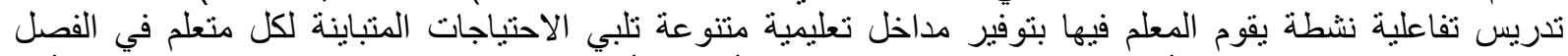

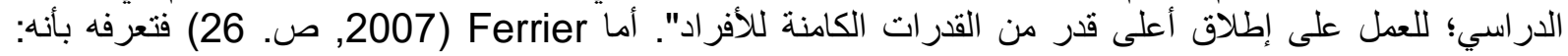

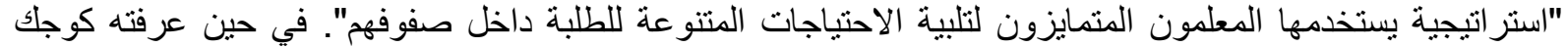

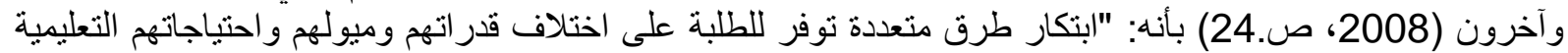

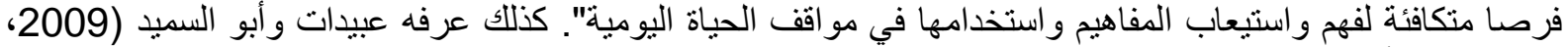

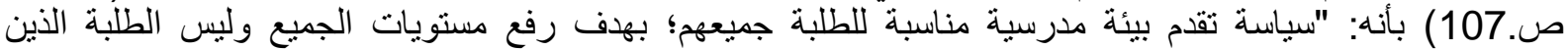

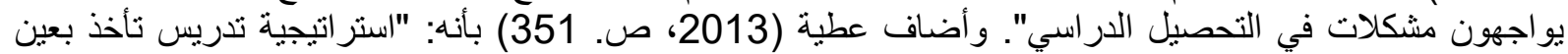

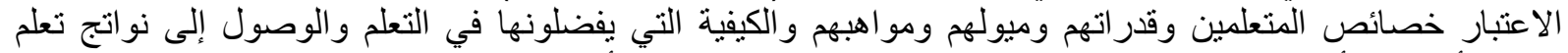

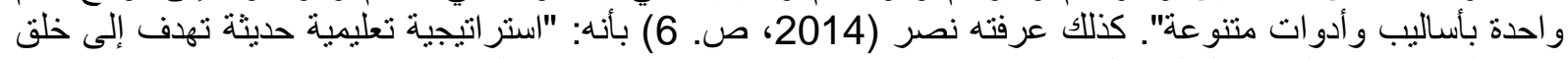

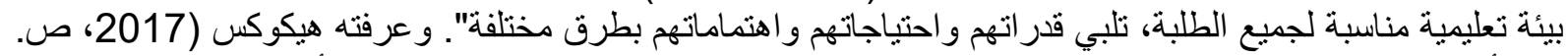

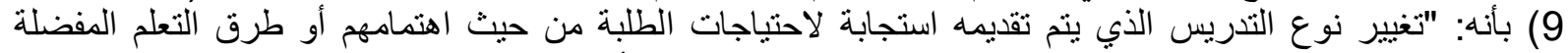

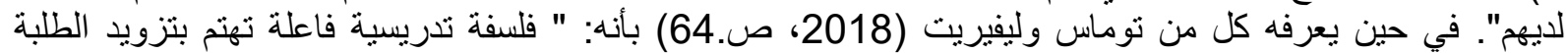

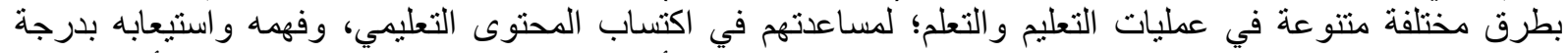

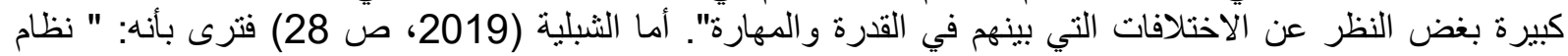
تدريسي يجمع بين مداخل واستر اتيجيات تدريسية متنو عة، يتعرف من خلالها إلى احتياجات المتعلمين وقدر اتهم المختلفة؛ 
بهدف رفع مستوى جميع الطلبة، ويُعد المتعلم فيه محور العملية التعليمية". ويتضح من خلال دراسة التعريفات السابقة

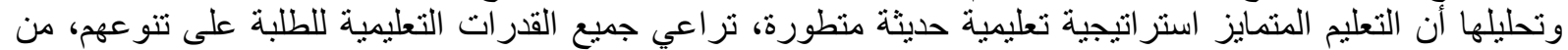

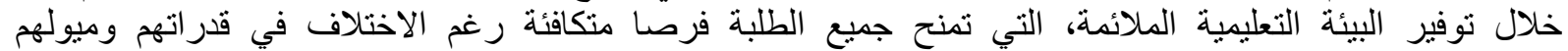

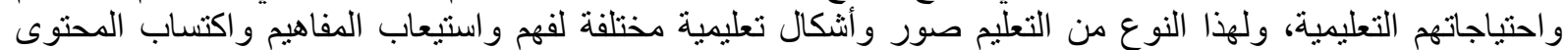
وبناء المعاني وصنع الأفكار، كما أنه يضمن لجميع التيع صنور الطلبة تحقيق نواتج التعلم المستهدفة نفسها.

منهج الاراسة اعتمدت الدراسة الحالية المنهج الوصفي، الذي يدرس المتغير ات المستقلة والتابعة ويصفها ويفسرها، ويتوصل من خلالها إلى حلول و إجر اءات ونوصيات ومقترحات تعالج المشكلة البحثية.

مجتمع الاراسة وعينتها تكوّن مجتمع الدراسة من جميع المعلمئمين الأورائل والمعلمات الأول للغة العربية في الحلقة الثانية من التعليم الأساسي في

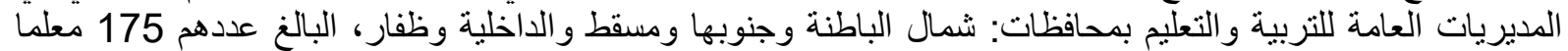

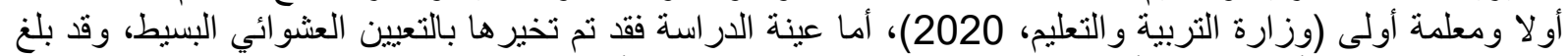

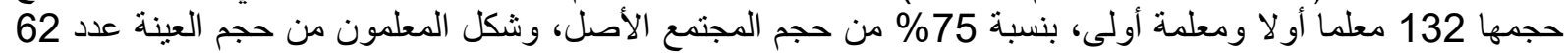

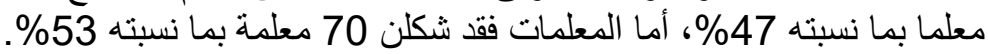

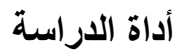

استبانة مهار ات التعليم المتمايز: وتكونت من ثلاثة محاور: المحور الأول وعنو انها مهار ات التخطيط، وقد تضمن 15

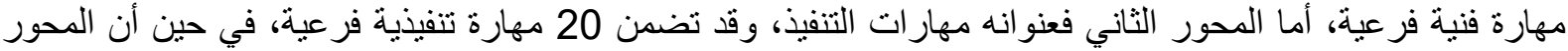

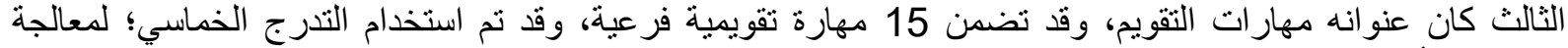

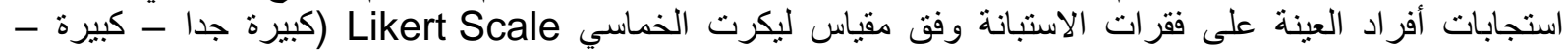

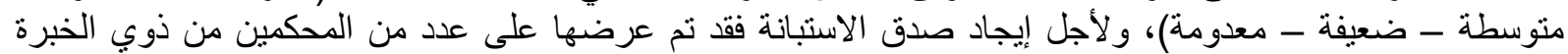

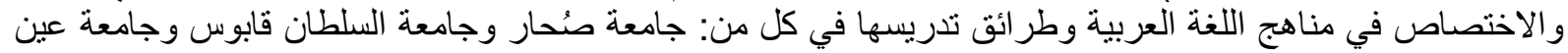

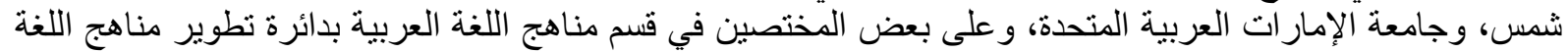

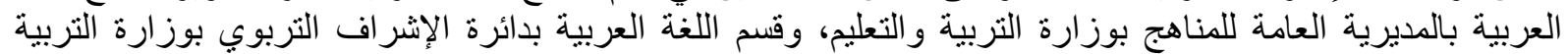

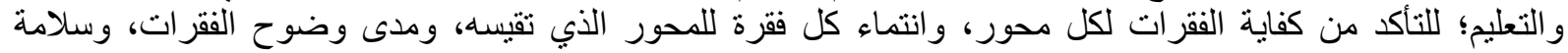

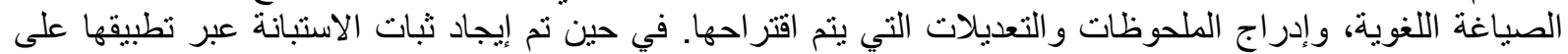

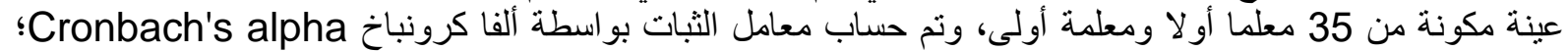
للتحقق من الاتساق الداخلي للأداة، وكان معامل الثبات للأداة (r=.88)، و هذا يشير إلى أن قيمة الثئ الثبات جيدة جدا؛ مما يدل على إمكانبة تطبيقها على عينة الدر اسة.

مناقثة النتائج وتفسير ها

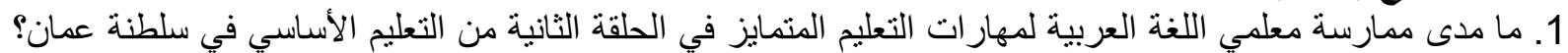

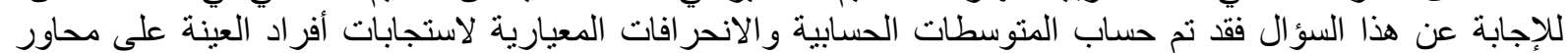
أداة الدراسة، و الجدول 1 يبين هذه النتائج.

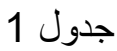

المتوسطات الحسابية والانحر افات المعيارية لممارسة معلمي اللغة العربية لمهارات التعليم المتمايز في الحلقة الثانية من التعليم الأساسي في سلطنة عمان الانس

\begin{tabular}{|c|c|c|c|c|}
\hline المستوى & 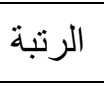 & الالمعرل ع. & المتوسط الحسابي & المحاور \\
\hline متوسطة & 2 & 0.61 & 3.29 & التخطيط للتعليم المتمايز \\
\hline متوسطة & 1 & 0.71 & 3.36 & التنفيذ للتعليم المتمايز \\
\hline ضعيفة & 3 & 0.42 & 2.55 & التقويم للتعليم المتمايز \\
\hline متوسطة & & 0.52 & 3.16 & المتوسط الكلي \\
\hline
\end{tabular}


أوضح الجدول 1 أن المتوسط الحسابي الكلي لمدى ممارسة معلمي اللغة العربية لمهار ات التعليم المنمايز في الحلقة الثانية

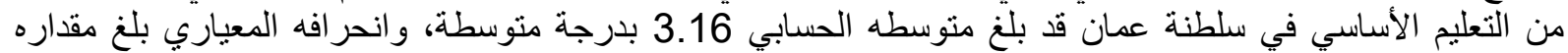

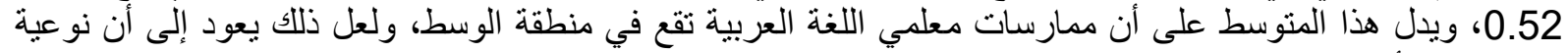

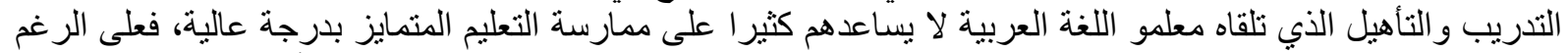

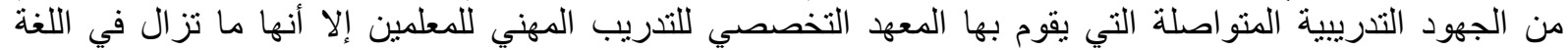

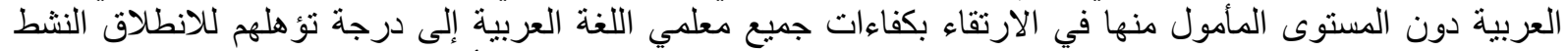

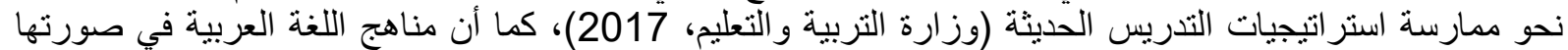

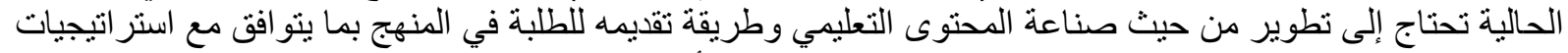

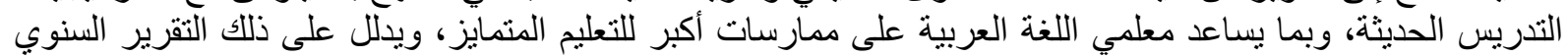

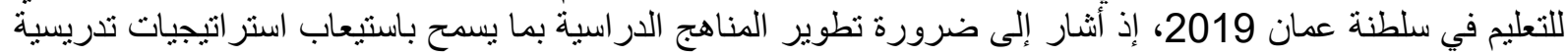
حديثة نشطة، تساعد المعلمين على الئضي نحو التجديد والتطوير في توظيف استراتيجيات التدريس النشطة (مجلس التعليم، 2019).

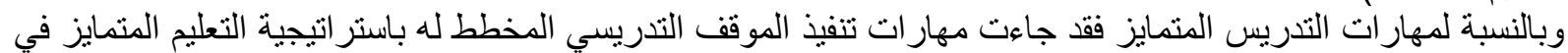

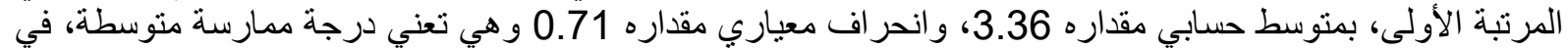

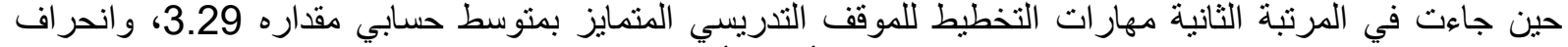

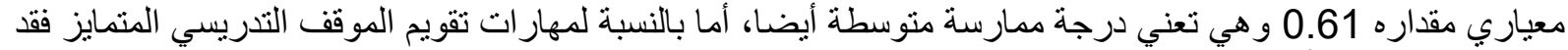

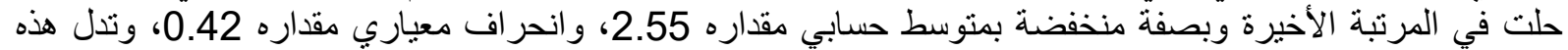

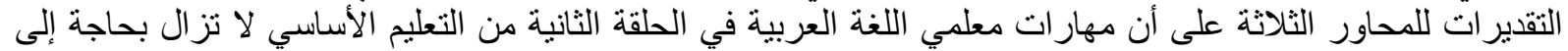

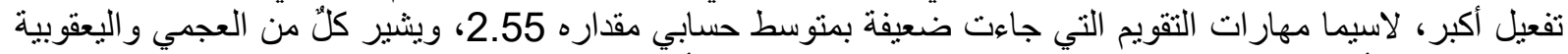

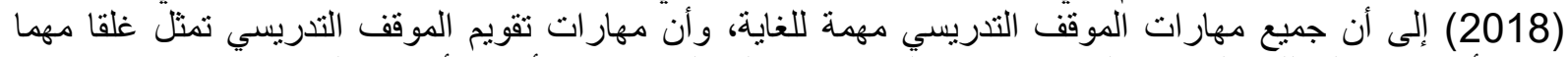

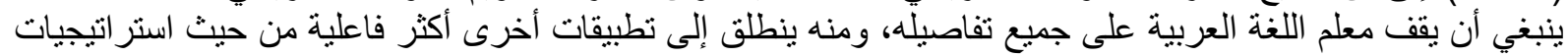
التدريس النشطة.

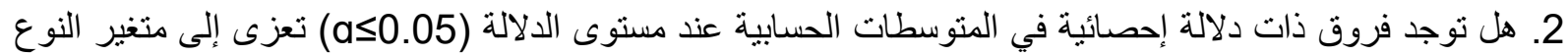

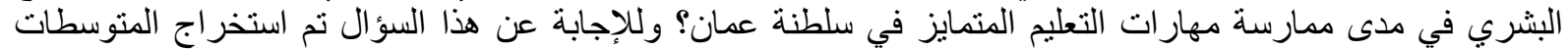

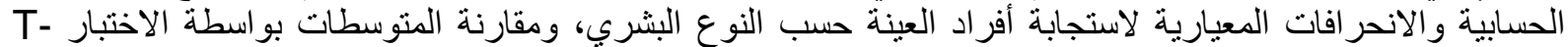

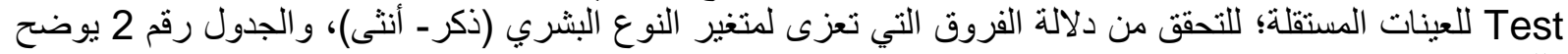

$$
\text { ذلك. }
$$

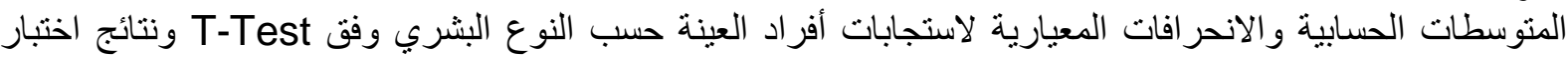

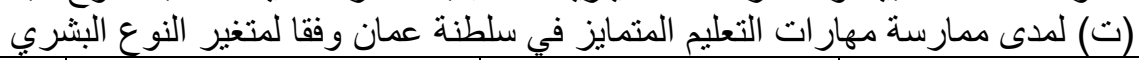

\begin{tabular}{|c|c|c|c|c|c|c|c|}
\hline \multirow[b]{2}{*}{ الاحتمالية } & \multirow[b]{2}{*}{ قيمة (ت) } & Df & \multicolumn{2}{|c|}{ الإناث (ن = 70) } & \multicolumn{2}{|c|}{ الذكور (ن* = 62) } & \multirow[b]{2}{*}{ المتمارسة التعليم } \\
\hline & & الحرية & الالحعر اف & الحسابي & الالمعراف & الحسابي & \\
\hline .936 & 115 & 0.08 & 0.36 & 3.81 & 0.32 & 3.81 & التخطيط $\quad$ التمايز $\quad$ للتعليم \\
\hline .004 & 113 & 2.92 & 0.56 & 3.61 & 0.48 & 3.50 & التنفيذ للتعليم المتمايز \\
\hline .255 & 116 & 1.14 & 0.39 & 3.39 & 0.39 & 3.32 & التقويم للتعليم المتمايز \\
\hline
\end{tabular}

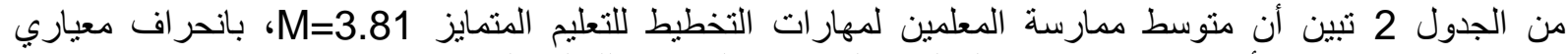
مقداره SD=0.32، وأن منوسط ممارسة المعلمات لمهارات التخطيط للتحليم المتمايز مقداره SD=0.36، كما أن متوسط ممارسة المعلمين لمهارات تتفيذ التعليم المتمايز مقداره SD=0.48، وأن متوسط ممارسة المعلمات لمهار ات تنفيذ التعليم المتمايز

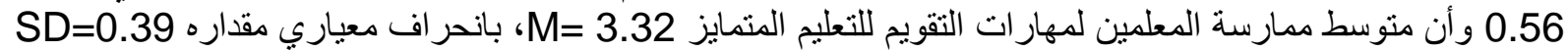




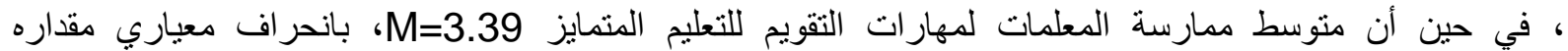

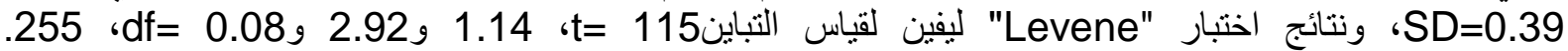

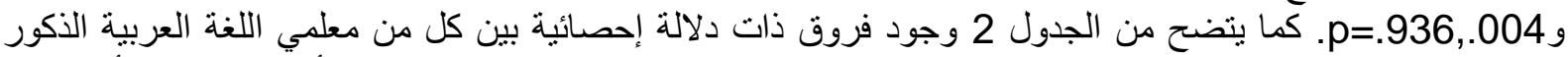

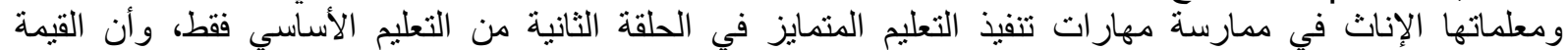

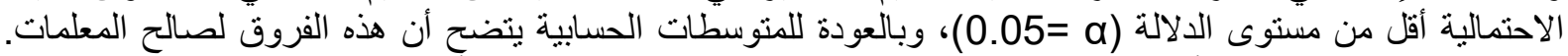

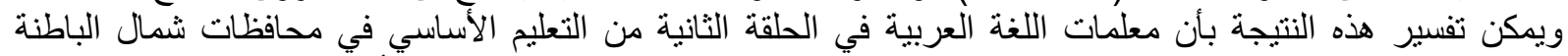

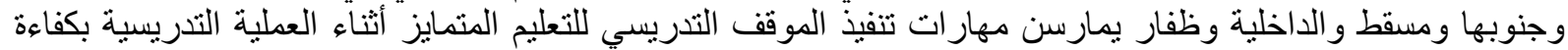

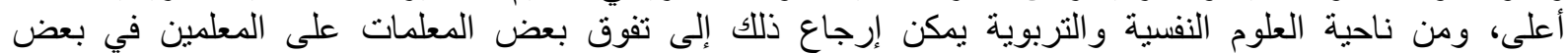

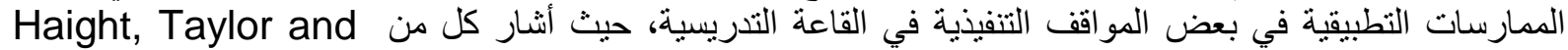
Elnekave (2020) أن وظائف القشرة الدماغية تشير إلى أن الإناث أفضل في المهار ات التطبية التطبيقية من الذكور . ويمكن

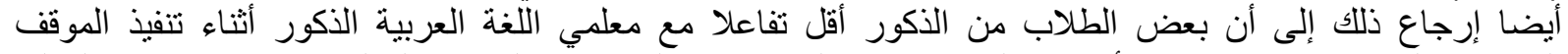

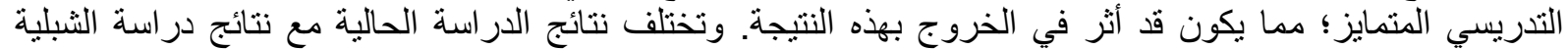

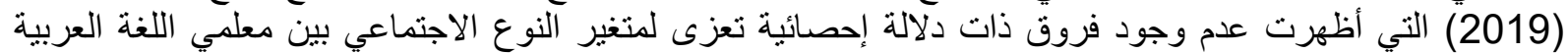
ومعلماتها في استخدام التعليم المتمايز.

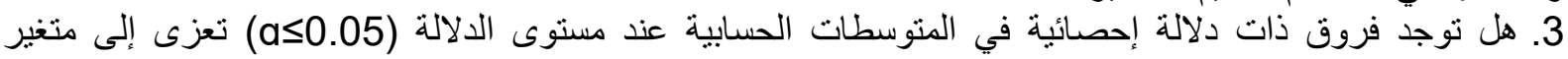

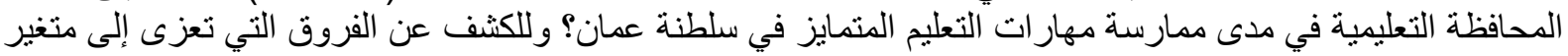

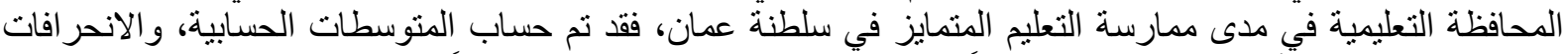

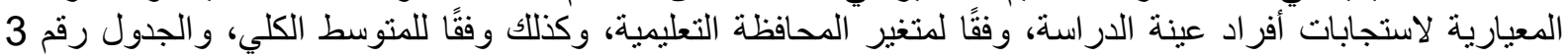
يوضح هذه النتائج.

جدول 3 المتوسطات الحسابية والانحر افات المعيارية لمدى ممارسة معلمي اللغة العربية لمهارات التعليم المتمايز في الحلقة الثانية

\begin{tabular}{|c|c|c|c|}
\hline \multicolumn{4}{|c|}{ من التعليم الأساسي في سلطنة عمان } \\
\hline الانحر اف المعياري & المتوسط الحسابي & عدد العينة & المحافظة التعليمية \\
\hline 0.59 & 3.31 & 30 & 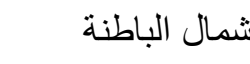 \\
\hline 0.71 & 3.22 & 25 & جنوب الباطنة \\
\hline 0.55 & 3.40 & 31 & مسقط \\
\hline 0.71 & 3.27 & 25 & 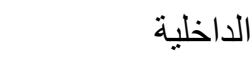 \\
\hline 0.73 & 3.10 & 21 & 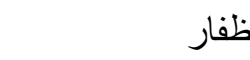 \\
\hline
\end{tabular}

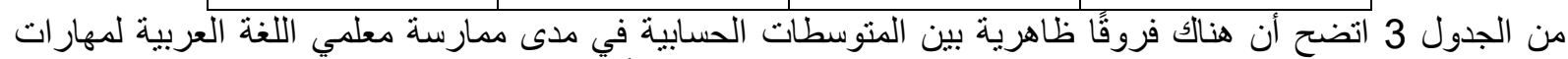

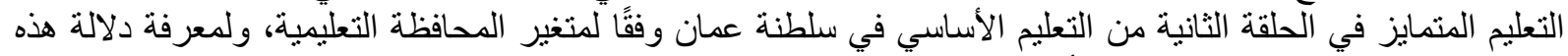
الفروق فقد نم استخدام تحليل التباين الأحادي (One-Way Anova).

جدول 4 نتائج تحليل التباين الأحادي للفروق في مدى ممارسة معلمي اللغة العربية لمهارات التعليم المتمايز في الحلقة الثانية من التعليم الأساسي في سلطنة عمان والتين وفقا لتنغير المحافظة التعليمية

\begin{tabular}{|c|c|c|c|c|c|c|}
\hline الاحتمالية القيمة & $F$ & متوسط & درجات & المربعوع & مصدر التباين & المتغير \\
\hline \multirow{3}{*}{0.249} & \multirow{3}{*}{1.40} & 0.52 & 2 & 1.04 & بين المجمو عات & \multirow{3}{*}{ شمال الباطنة } \\
\hline & & 0.37 & 241 & 90.07 & داخل المجمو عات & \\
\hline & & & 243 & 91.11 & المجموع & \\
\hline 0.202 & 1.61 & 0.81 & 2 & 1.61 & بين المجموعات & جنوب الباطنة \\
\hline
\end{tabular}




\begin{tabular}{|c|c|c|c|c|c|c|}
\hline & & 0.50 & 241 & 120.41 & داخل المجمو عات & \\
\hline & & & 243 & 122.02 & المجموع & \\
\hline \multirow{3}{*}{0.239} & \multirow{3}{*}{1.44} & 0.87 & 2 & 1.74 & بين المجموعات & \multirow{3}{*}{ مسقط } \\
\hline & & 0.60 & 241 & 145.48 & داخل المجمو عات & \\
\hline & & & 243 & 147.22 & المجموع & \\
\hline \multirow{3}{*}{0.249} & \multirow{3}{*}{1.40} & 0.81 & 2 & 1.61 & بين المجموعات & \multirow{3}{*}{ الداخلية } \\
\hline & & 0.50 & 241 & 120.41 & داخل المجمو عات & \\
\hline & & & 243 & 122.02 & المجموع & \\
\hline \multirow{3}{*}{0.202} & \multirow{3}{*}{1.61} & 0.52 & 2 & 1.04 & بين المجمو عات & \multirow{3}{*}{ ظفار } \\
\hline & & 0.37 & 241 & 90.07 & داخل المجمو عات & \\
\hline & & & 243 & 91.11 & المجموع & \\
\hline \multirow{3}{*}{0.204} & \multirow{3}{*}{1.60} & 0.70 & 2 & 1.41 & بين المجمو عات & \multirow{3}{*}{ المتوسط الكلي } \\
\hline & & 0.44 & 241 & 105.94 & داخل المجمو عات & \\
\hline & & & 243 & 107.35 & المجموع & \\
\hline
\end{tabular}

أظهر الجدول 4 عدم وجود فروق ذات دلالة إحصائية في مدى ممارسة معلمي اللغة العربية لمهارات التعليم المتمايز في التي التئي

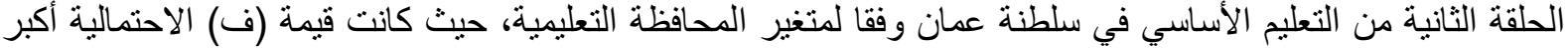

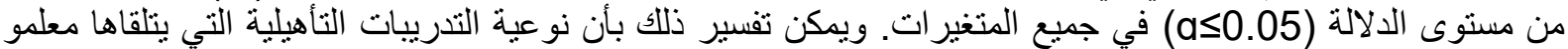

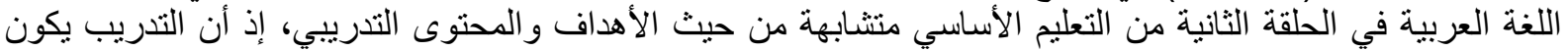

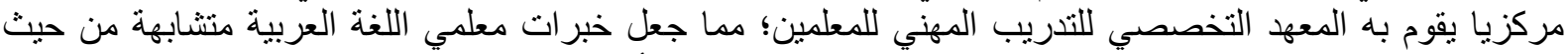

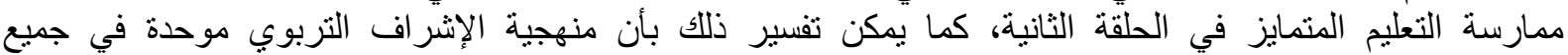

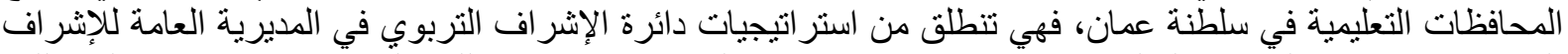

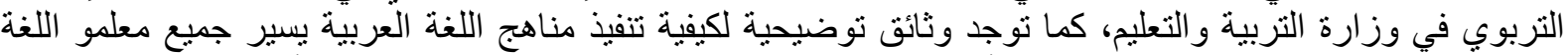

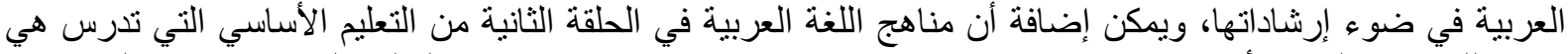

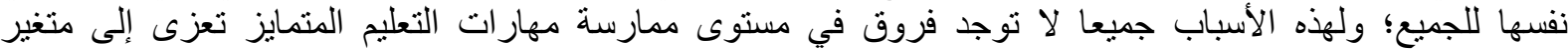
التوصيات 1. تعزيز معلمي اللغة العربية في الحلقة الثانية من التعليم الأساسي الذين يمارسون التعليم المتمايز؛ لزيادة الإقبال عليه

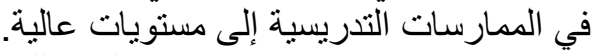

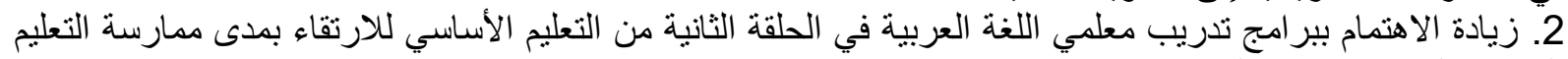
المنمايز إلى مستويات عالية. 3. تطوير قدرات الإشر افت التربوي ليستطيع المساهمة الفاعلة في تطوير ممارسة معلمي اللغة العربية في الحلقة الثانية

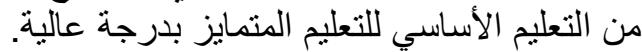

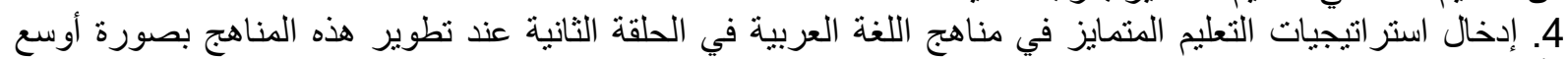
و أكثر إجر ائية.

المقترحات 1. إجر اء مزيد من الدراسات والبحوث باستخدام متغيرات أخرى حول التعليم المتمايز واستر اتيجيات تفعيله في الحقل

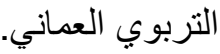
2. تقويم مناهج اللغة العربية في الحلقة الثانية من التعليم الأساسي في ضوء مر اعاتها لمهار ات التعليم المتمايز. 


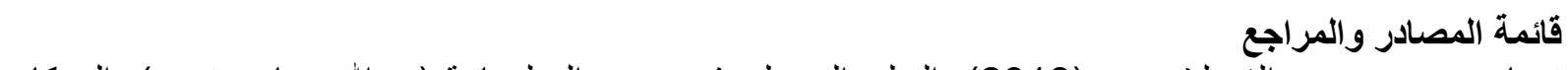

توماس، روزبرو، ور الف ليفيريت. (2018). التعليم التحويلي في عصر المعلوماتية (عبداله وسام، مترجم). العبيكان كارول للشر و التوزيع.

توملينسون، كارول. (2016). الصف المتمايز الاستجابة لاحتياجات كل المتعلمين. (ترجمة: مكتب التربية العربي لدول

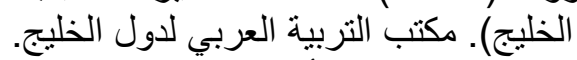

الحوسنية، عفراء علي. (2019، أبريل 4-2). التعليم المنمايز وإستراتيجياته. مؤنمر التربية والتعليم العالي في الوطن

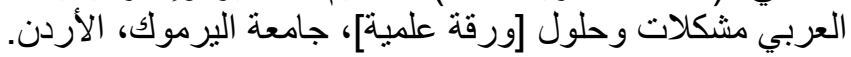

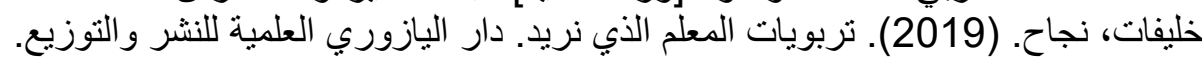

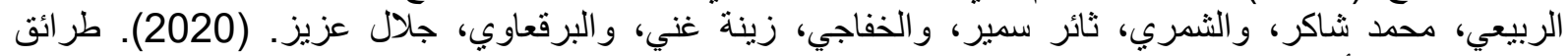

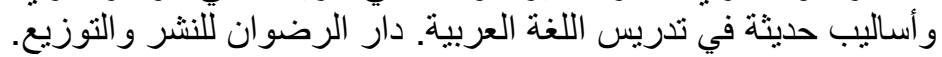

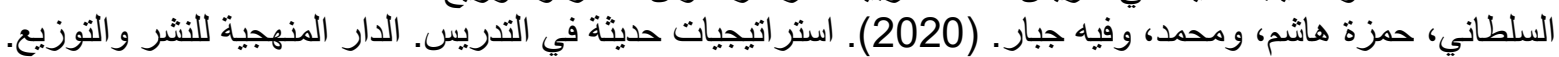

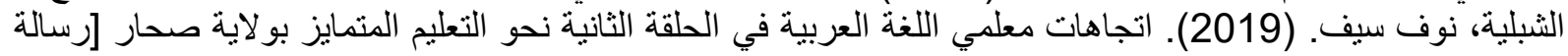

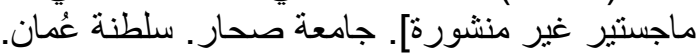

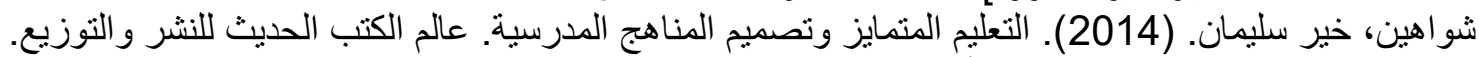

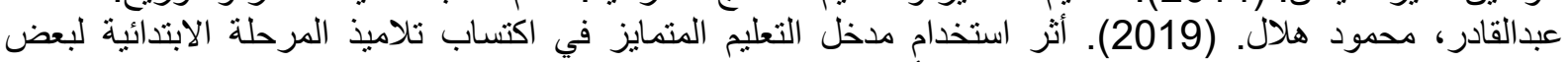

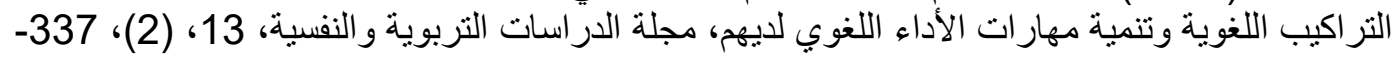

.367

عبيدات، ذوقان، و أبو السميد، سهيلة. (2013). إستراتيجيات التدريس في القرن الحادي و العشرين دليل المعلم و المشرف التربوي. دار ديبونو للطباعة والنشر و التوزيع.

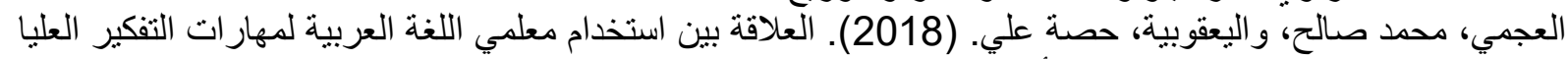

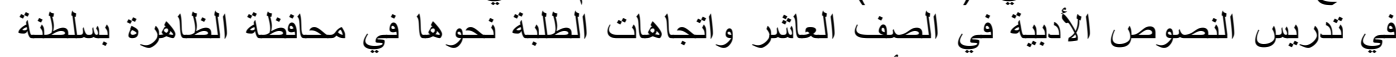

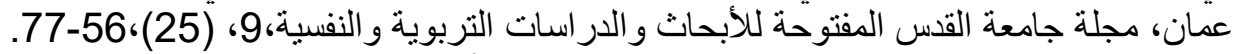

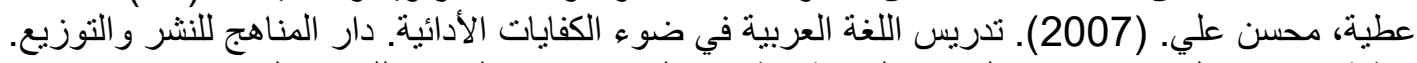

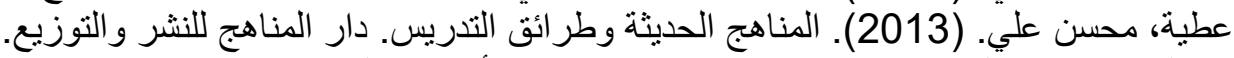

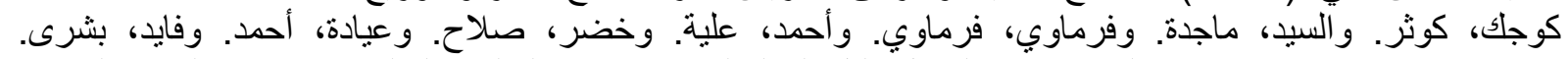

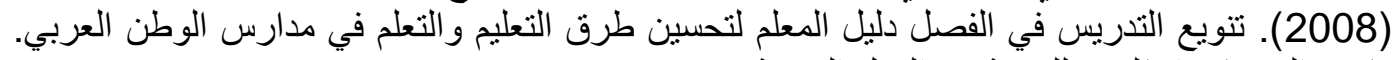

مكتب اليونسكو الإقليمي للتربية في الني في الدول العربية.

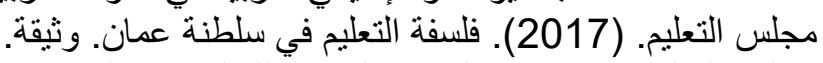

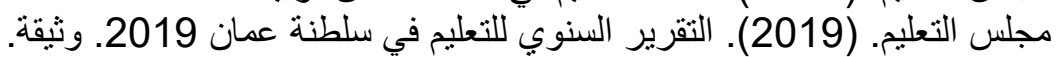

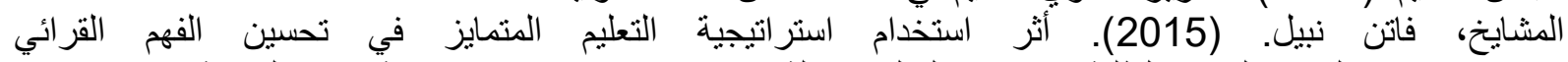

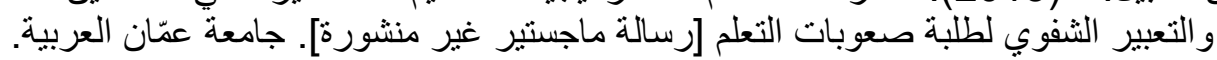

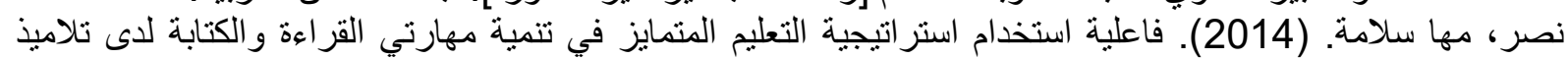

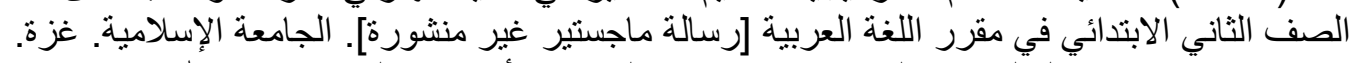

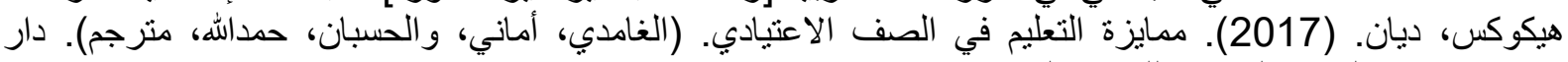

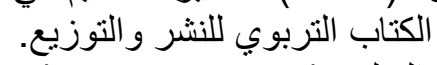

وزارة التربية والتعليم. (2017، ديسمبر 10). ملتقى تقنيات التدريب الدديثة وعو ائد التعليم. المركز التخصصي للتدريب

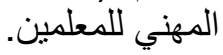

وزرة التربية والتعليح. (2020) الكتاب السنوي للإحصاءات التعليمية، العدد 50.

Coil, C. (2007). Successful Teaching in the Differentiated Classroom. Pieces of learning.

Ducey, M. (2011). Improving Secondary Science Achievement Through the Implementation of Differentiated Instruction. University of Memphis.

Ferrier, A. (2007). The effects of differentiated instruction on academic achievement in a second-grade science classroom. Walden University.

Gangi, S. (2011). Differentiated Instruction Using Multiple Intelligences in the Elementary School Classroom; A Literature Review Graduate Degree/Major: MS Education (Doctoral dissertation, University of Wisconsin-Stout). 
Haight, H. Taylor, E. Elnekave, R. (2020). Human Behavior for Social Work Practice, Oxford university press.

Hattie, J. (2019). Visible Learning for Teachers: Maximizing Impact on Learning. Routledge.

Koeze, P. (2007). Differentiated instruction: The effect on student achievement in an elementary school. Walden University.

Stephen, J; Marlene, T; Gerard, M; Leela, R. (2013). The Impact of Differentiated Instruction in a Teacher Education Setting: Successes and Challenges. International Journal of Higher Education, 2 (3), 28-40.

Ziebell , J. ( 2002). Differentiated Instruction. Levine. 